\title{
Correlation and Path Coefficient Analyses in Sugarcane
}

\author{
Rewati R Chaudhary ${ }^{1}$ and Bal K Joshi ${ }^{2}$ \\ ${ }^{1}$ Sugarcane Research Programme-NARC, Jitpur-Bara-Nepal \\ ${ }^{2}$ Biotechnology Unit-NARC, Khumaltar-Lalitpur-Nepal
}

\begin{abstract}
This study was conducted to determine the contribution of different traits to cane yield in sugarcane (Saccharum officinarum L). Sixty-five clones were evaluated in a replicated field experiment at Sugarcane Research Programme, Jitpur, Nepal in 2003 for six morphological characters under irrigated conditions. Analysis of variance revealed significant differences for all the characters studied. Cane yield showed positively and highly significant correlation with single cane weight, stalk length and millable cane number. There was also positively significant correlation of cane diameter and number of internode with cane yield. Length of internode had positive non-significant correlation with cane yield. Single cane weight had the highest positive direct effect on cane yield followed by millable cane number. Stalk diameter and stalk length was positively and significantly correlated with cane yield, which was due to indirect effect of single cane weight. Results indicate that the genotypes should be selected on the basis of single cane weight and millable cane number for getting higher sugarcane yield.
\end{abstract}

Key words: Cane yield, correlation, path coefficient, sugarcane

\section{INTRODUCTION}

Sugarcane is one of the most important crops in the world (Dagar et al 2002). In Nepal it is the third largest agro industry crop next to grain and oil mills (Shakya 2001). Sugarcane is being cultivated in around 59477 ha, producing 2.2 million tons of cane with approximately 37.79 tons per hectare during 2001 in Nepal (Chaudhary 2002). Sugarcane breeding involves the production and evaluation of several thousand seedlings from different crosses every year and selection of the superior seedlings for further evaluation in clonal stages (Sundaresan et al 1979). The subsequent selection in successive clonal generations require considerable amount of labour and fund.

Path coefficient is an excellent means of studying direct and indirect effects of interrelated components of a complex trait (Kang et al 1989). Path-coefficient analysis measures the direct influence of one variable on another. Each correlation coefficient between a predictor variable and the response variable is partitioned into its component parts: the direct effect or path coefficient (a standardized partialregression coefficient) for the predictor variable and indirect effects, which involve the product of a correlation coefficient between two predictor variables with the appropriate path coefficient in the path diagram (Dewey and Lu 1959). By determining the inter-relationships among grain yield components, a better understanding or both the direct and indirect effects of the specific components can be attained. Effects of stalk number, stalk diameter, stalk length and single cane weight on cane yield have been reported by Hogarth (1971), Chaudhary et al (1994) and James (1971). Plant breeders generally select for only a few traits and it is very important to know the effects of this on other important characters as well. Therefore, this experiment was conducted to study the relations of certain morphological characters with sugarcane yield. 


\section{MATERIALS AND METHODS}

Sixty-five clones of sugarcane developed at different research stations of India and local cultivars collected from different parts of Nepal that belonged to different maturity groups were planted in a randomized block design with two replications at Sugarcane Research Programme, Jitpur during 2003. The plot size was $4-\times 1.8-\mathrm{m}$ with 2 rows and row-to-row distance was $90 \mathrm{~cm}$. The seed was planted on 07 Feb 2003 and crop duration was 360 days. Three budded setts of cane were planted at the rate of 12 buds per meter in furrow method. The fertilizers were used at the rate of 75:60:40 kg N:P:K ha ${ }^{-1}$ at the time of planting and $75 \mathrm{~kg} \mathrm{~N} \mathrm{ha}^{-1}$ in two equal split, first at 90 and second at 120 days after planting. Regarding interculture operations, 3 hand weedings and one earthing up were done. The observations were recorded for millable cane number, stalk length, stalk diameter, number of internode, length of internode and cane yield. Pearson correlation coefficient were estimated among these variables as suggested by Steel and Tori (1980). Correlation coefficient was calculated using INSTAT software. The total correlation coefficients of various yield contributory characters with regard to cane yield was partitioned into components of direct and indirect effects following the method adopted by Dewey and Lu (1959).

\section{RESULTS AND DISCUSSION}

There were significant differences among the genotypes for all characters under studied (Table 1). This can be attributed to the fact that these clones were derived from parents having different genetic and geographic backgrounds.

Table 1. Means of sum of square for stalk characters in 65 sugarcane clones

\begin{tabular}{lllllllll}
\hline Source & df & $\begin{array}{l}\text { No of } \\
\text { millable } \\
\text { cane }\end{array}$ & $\begin{array}{l}\text { Stalk } \\
\text { length }\end{array}$ & $\begin{array}{l}\text { No of } \\
\text { internode }\end{array}$ & $\begin{array}{l}\text { Length of } \\
\text { internode }\end{array}$ & $\begin{array}{l}\text { Cane } \\
\text { diameter }\end{array}$ & $\begin{array}{l}\text { Single cane } \\
\text { weight }\end{array}$ & $\begin{array}{l}\text { Cane } \\
\text { yield }\end{array}$ \\
\hline Replication & 1 & 59.57 & 4.8 & 0.069 & 2.4923 & 0.000443 & 0.004923 & 76.34 \\
Genotypes & 64 & $393.15^{* *}$ & $708.7^{* *}$ & $15.266^{* *}$ & $2.8043^{*}$ & $0.036384^{* *}$ & $0.018574^{* *}$ & $206.56^{* *}$ \\
Error & 64 & 32.04 & 104.7 & 3.160 & 0.8113 & 0.004990 & 0.001235 & 10.81 \\
\hline
\end{tabular}

*, ** Significant at 0.05 and 0.01 probability levels, respectively.

\section{Correlation}

The pair wise simple correlation coefficient (r) among various characters are presented in Table 2. Cane yield was positively and highly significant correlation with single cane weight $\left(\mathrm{r}=0.68^{* *}\right)$, stalk length $\left(\mathrm{r}=0.61^{* *}\right)$ and millable cane number $\left(\mathrm{r}=0.37^{* *}\right)$. There was also positive significant correlation of cane yield with cane diameter $\left(r=0.31^{*}\right)$ and number of internode $\left(r=0.27^{*}\right)$. A positive value of $r$ shows that the changes of two variables are in the same direction, ie high values of one variable are associated with high values of other and vice versa. A positive and highly significant correlation between cane yield and its components, viz single cane weight, stalk length and millable cane number was reported by Brown et al (1969), Balasundarum and Bhagyalakshmi (1978) and Punia et al (1983). Hooda et al (1979) also observed cane diameter having significant positive correlation with cane yield. Length of internode had positive non-significant correlation with cane yield. Millable cane number was negatively significant correlation with cane diameter $\left(\mathrm{r}=-0.36^{* *}\right)$ and single cane weight $\left(\mathrm{r}=-0.26^{*}\right)$. Balasundarum and Bhagyalakshmi (1978) also reported similar results. Negative correlation indicated their inverse relationship with each other. Single cane weight was positively and highly significant correlation with stalk length and cane diameter. Stalk length was positively and highly significant correlation with number of internode and length of internode. Whereas, number of internode had positive but non-significant correlation with length of internode $(r=0.15)$ and single cane weight $(r=$ 
0.23). Length of internode had also non-significant correlation with cane diameter $(r=0.091)$ and single cane weight. It is obvious that single cane weight, stalk length, millable cane number, stalk diameter and number of internode can be considered together in a positive direction towards an ultimate aim of developing high yielding sugarcane clone.

Table 2. Correlation coefficients among different characters in 65 sugarcane genotypes grown at Jitpur

\begin{tabular}{llllllll}
\hline SN & Character & 1 & 2 & 3 & 4 & 5 & 6 \\
\hline 1 & Number of millable cane & & & & & & \\
2 & Stalk length & -0.0021 & & & & & \\
3 & Number of internode & 0.1309 & $0.4104^{* *}$ & & & & \\
4 & Length of internode & 0.0075 & $0.3448^{* *}$ & 0.1584 & & & \\
5 & Cane diameter & $-0.3621^{* *}$ & $0.4767^{* *}$ & $0.3533^{* *}$ & 0.091 & & \\
6 & Single cane weight & $-0.2584^{*}$ & $0.6173^{* *}$ & 0.2337 & 0.199 & $0.5983^{* *}$ & \\
7 & Cane yield & $0.3735^{* *}$ & $0.6059^{*}$ & $0.2691^{*}$ & 0.1866 & $0.3092^{*}$ & $0.6836^{* *}$ \\
\hline$*, * *$ & Significant at $5 \%$ and 1\% respectively. & & & & &
\end{tabular}

\section{Path coefficient analysis for cane yield}

Path coefficient analysis unfolds whether the association of cane yield with its components is due to the direct effects of component characters on cane yield or is a consequence of its indirect effects via some other traits. The highest positive direct effect on cane yield was exerted by single cane weight $(0.728)$ followed by millable cane number (0.576) (Table 3). The direct effect of single cane weight on cane yield was also reported by Punia et al (1983), Reddy and Reddy (1986) and Hooda et al (1988). A direct effect of millable cane on cane yield was similar to the findings of Balasundarum and Bhagyalakshmi (1978), Kang et al (1989), Punia et al (1983) and Chaudhary and Singh (1994). It was observed that stalk length and stalk diameter was positive significant correlation with cane yield. Their direct effects on cane yield were positive but low and negligible. Significant correlation was due to indirect effects of single cane weight. Internode number and internode length had negative negligible direct effects on cane yield. This implied that selection of sugarcane genotypes on the basis of stalk weight and millable cane number would be beneficial for increasing sugarcane yield.

Table 3. Path coefficients showing direct (diagonal) and indirect effects of 6 components on cane yield

\begin{tabular}{llrrrrrr}
\hline SN & Characters & 1 & 2 & 3 & 4 & 5 & 6 \\
\hline 1 & Number of millable cane & $\mathbf{0 . 5 7 6}$ & -0.0003 & -0.007 & -0.0001 & -0.007 & -0.188 \\
2 & Stalk length & -0.001 & $\mathbf{0 . 1 7 6}$ & -0.021 & -0.006 & 0.009 & 0.449 \\
3 & Number of internode & 0.075 & 0.072 & $\mathbf{- 0 . 0 5 2}$ & -0.003 & 0.006 & 0.170 \\
4 & Length of internode & 0.005 & 0.061 & -0.008 & $\mathbf{- 0 . 0 1 7}$ & 0.002 & 0.145 \\
5 & Cane diameter & -0.209 & 0.084 & -0.018 & -0.002 & $\mathbf{0 . 0 1 8}$ & 0.435 \\
6 & Single cane weight & -0.149 & 0.109 & -0.012 & -0.003 & 0.011 & $\mathbf{0 . 7 2 8}$ \\
\hline
\end{tabular}

*, ** Significant at $5 \%$ and $1 \%$ respectively. Residual $=0.43$.

Correlation study indicates that stalk length and single cane weight are most important for cane yield improvement. Selection based on number of millable cane and single cane weight are directly increased cane yield. During selection indirect effect of stalk length via single cane weight should also be considered. Three characters viz stalk length, millable cane number and single cane weight are very important that can be considered during breeding programme. For more reliable information, these coefficients should be separated in environmental, genotypic and phenotypic parts. 


\section{REFERENCES}

Balasundaram N and B Bhagyalakshmi. 1978. Variability, heritability and association among yield and yield components of sugarcane. Indian J. of Agric. Sci. 48:291-295.

Brown AHD, J Daniels and BHD Latter. 1969. Quantitative genetics of sugarcane 11. Correlation analysis of continuous character in relation to hybrid sugarcane breeding. Theoretical Applied Genetics 39:478-481.

Chaudhary AK and JRP Singh. 1994. Correlation and path coefficient studies in early maturing clone of sugarcane (Saccharum spp. Complex). Cooperative Sugar B25B:305-307.

Chaudhary RR. 2002. National report on sugarcane. Paper presented in 25th Winter Crops Research Workshop, 11-12 September 2002. Nepal Agricultural Research Council, Khumaltar, Lalitpur.

Dagar P, SK Pahuja, SP Kadian and S Singh. 2002. Evaluation of phenotypic variability in sugarcane using principal factor analysis. Indian Journal of Sugarcane Technology 17:95-100.

Dewey DR and KH Lu. 1959. A correlation and path coefficient analysis of components of crested wheat grass seed production. Agron. J. 51:515-518.

Hogarth OM. 1971. Quantitative inheritance studies in sugarcane. 11. Correlations and predicted responses to selection. Aust. J. Agric. Res. 22:103-109.

Hooda MS, S Singh and BS Chaudhary. 1988. Correlation and path coefficient analysis in sugarcane. Crop Improvement 15:206-208.

Hooda RS, CN Babu and LS Khairwal. 1979. Association and path analysis of nine characters in progenies of four sugarcane crosses at settling stage. Indian J. Agric. Sci. 49:931-33.

James NI. 1971. Yield components in random and selected sugarcane populations. Crop Sci. 11:906-908

Kang MS, O Sosa and JD Miller. 1989. Path analysis for percent fiber and cane and sugar yield in sugarcane. Crop Sci. 29:1481-3.

Patel MM, HS Patel, AD Patel and MP Patel. 1993. Correlation and path analysis in sugarcane. Indian Sugar 43:365-8.

Punia MS, R Paroda and RS Hooda. 1983. Correlation and path analysis of cane yield in sugarcane. Indian J. Genet. Plant Breed. 43:109-12.

Reddy CR and MV Reddy. 1986. Degree of genetic determination, correlation and genotypic and phenotypic path analysis of cane and yield in sugarcane. Indian J. Genet. 46:550-7.

Shakya DB. 2001. Sugar industries in Nepal. Paper presented in Ethanol and Sugar Commerce Workshop, New Delhi, India, IBC Asia Limited Singapore.

Steel, RGD and JW Torrie. 1980. Principles and procedures of statistics with special reference to the biological science. McGraw Hill Book Company, INC. New York.

Sundaresan K, N Balasundaram and S Shunmugasundaram. 1979. Correlation between seedlings and their settlings in intervarietal crosses of sugarcane for major economic characters. Indian J. Agric. Sci. 49(12):9347. 